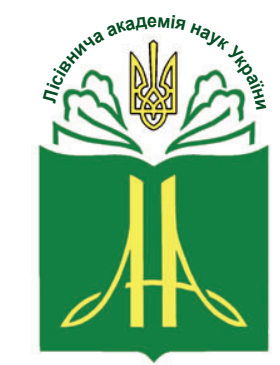

Forestry Academy of Sciences of Ukraine

Наукові праці Лісівничої академії наук України Proceedings of the Forestry Academy of Sciences of Ukraine

http://fasu.nltu.edu.ua https://doi.org/10.15421/412005

Article received 2019.11.25

Article accepted 2020.06.04
ISSN 1991-606X print

ISSN 2616-5015 online

@ $₫$ Correspondence author

Yaroslav Fuchylo

fuchylo_yar@ukr.net

v. Hamarnya, Malyn district, Zhytomyr region, 11643, Ukraine

\title{
Вплив метеорологічних чинників на радіальний приріст дуба звичайного в умовах свіжих і вологих сугрудів Полісся України
}

\author{
І.Д. Іванюк', Я.Д. Фучило²
}

Встановлено оптимальні параметри метеорологічних чинників, які забезпечують максимальний приріст штучних насаджень дуба звичайного за діаметром в умовах свіжих $і$ вологих сугрудів Центрального Полісся Украӥни.

Аналіз залежностей між метеорологічними чинниками і радіальним приростом дерев дуба за період 19462018 рр. показав, щзо незначний позитивний вплив на радіальний приріст виявляють річна сума опадів ( $r=0,16)$, сума опадів за вегетаиійний період $(r=0,22)$ та опади осінніх і зимових місяців попереднього року $(r=0,14)$. Встановлено, щзо роки найбільш високих і низьких величин радіального приросту слабо відрізняються за середньомісячними температурами повітря. У той же час встановлено наявність тісного зв'язку індексу ширини річного кільияя з показниками гідротермічного коефіцієнта - відношення суми опадів (P) за вегетаційний період до десятої частини суми температур ( $t$ ) вище $10^{\circ} \mathrm{C}\left(\Gamma T K=P / 0,1 \sum t_{\geq 10^{\circ} \mathrm{C}}\right)$. У понад 90\% дерев дуба звичайного підвищені прирости з індексом > 80 формуються в роки з ГТК від 1,4 до 1,8. За межами ичього інтервалу знаходиться зона пригнічення росту дерев зі зниженими індексами радіального приросту.

На основі математичного моделювання залежності між індексом радіального приросту і гідротермічним коефіцієнтом встановлено, щзо оптимальними для росту деревостанів дуба звичайного є показники ГТК для свіжих і вологих сугрудів, відповідно, 1,65 та 1,62. При изьому, індекс радіального приросту значно більший у свіжому сугруді (125,7 проти 114,8 у вологих умовах), щчо вказує на більшу чутливість дерев дуба звичайного у свіжому сугруді до зміни погодних умов.

Виявлені кореляційні зв'язки параметрів радіального приросту з кліматичними показниками у наступних дослідженнях можуть бути використані для побудови реконструкиій клімату та прогнозу продуктивності дубових деревостанів у майбутньому.

Ключові слова: Quеrсus robur L.; деревостани старших вікових груп; кількість опадів; сума температур повітря; гідротермічний коефіцієнт; річний приріст за діаметром; індекс радіального приросту дерев.

Вступ. Дерева, як своєрідна життєва форма, мають здатність до внутрішньої компенсації і стабілізації своїх ростових і морфологічних реакцій на дію зовнішніх чинників. При цьому об'єктивним індикатором змін, які відбуваються у природному середовищі, біологічним маркером кліматичного, лісівничого та інших впливів на ріст деревного виду є річний радіальний приріст, його кількіс-

Іванюк Ігор Дмитрович - кандидат сільськогосподарських наук, доцент, директор Малинського лісотехнічного коледжу, представник Колективного члена ЛАН України. 11643, с. Гамарня Малинського району Житомирської області, Україна. Тел.: +38-041-336-85-13. E-mail: mltk-1927@ukr.net ORCID: http://orcid.org/0000-0002-4969-8783

2 Фучило Ярослав Дмитрович - академік Лісівничої академії наук України, доктор сільськогосподарських наук, професор, завідувач кафедри лісівництва та захисту лісу Малинського лісотехнічного коледжу, головний науковий співробітник Інституту біоенергетичних культур і цукрових буряків НААН України, вул. Клінічна, 25, м. Київ, 03141, Україна. Тел.: +38-067-605-91-41. E-mail: fuchylo_yar@ukr.net ORCID: http://orcid.org/0000-0002-2669-5176 
ні та якісні характеристики. Динаміка радіального приросту дерев відображає не тільки багаторічну мінливість, в якій фіксуються результати внутрішньовидової конкуренції між деревами, але й інші складні процеси, що відбуваються у природних угрупованнях, включаючи антропогенний чинник (Debryniuk, Krynitskyy, \& Tselen, 2016; Fuchylo, 2011; Kobal et al., 2015; Sopushynskyy, Kharyton, Teischinger, Mayevskyy, \& Hrynyk, 2019; Szaban, Kowalkowski, Karaszewski, \& Jakubowski, 2014; Wasik, Michalec, \& Barszcz, 2015). Тому, 3 погляду причинного аналізу деревостанів, які є головним продуцентом екосистеми, важливо вивчати радіальний приріст не тільки як показник біотичної продуктивності цих систем, але й як фактичну основу для оцінки багаторічної мінливості чинників, що визначають стійкість деревостану до стресових ситуацій, зокрема, з'ясування причин індивідуальної та групової мінливості під впливом метеорологічних чинників (Maksymchuk, Sopushynskyy, \& Tymochko, 2017).

Основними чинниками мінливості радіального приросту є температура повітря та сума опадів, про що свідчать численні публікації (Bitvinskas, 1987, 1998; Ivanyuk, Zborovska, \& Zhukovskyi, 2019; Kairukshtis, Galaziy, \& Shiyatov, 1986; Kazmierczak, Zawieja, 2014; Maksymchuk et al., 2018; OsazuwaPeters, Wright, \& Zanne, 2014; Sopushynskyy, 2016; Zhang, Jiang, Zhao, Jiao, \& Wen, 2018).

Деревні породи володіють певною стабільністю приросту, у зв'язку з чим незначний вплив будьякого чинника достатньою мірою може не проявлятися і під час виконання досліджень зазвичай не фіксується. Це істотно ускладнює аналіз залежностей між приростом і мінливістю погодних умов.

Вплив температури на величину щорічного радіального приросту простежено дендрокліматологами Норвегіï (Kairukshtis et al., 1986). Встановлено, що роки найбільш високих і низьких величин радіального приросту мало відрізняються за температурним режимом, зокрема - за середньомісячними температурами. Цей висновок узгоджується з даними Bitvinskas (1987, 1998), який не виявив корелятивного зв'язку між приростом і середніми температурами за червень-серпень.

Важливим показником, який, крім температурного режиму, враховує також вологозабезпечення території, $є$ гідротермічний коефіцієнт $(Г T K)$ - відношення суми опадів $(P)$ за вегетаційний період до десятої частини суми температур $(t)$ вище $10^{\circ} \mathrm{C}$ $\left(\Gamma T K=P / 0,1 \sum t_{>10^{\circ} \mathrm{C}}\right)$. Цей показник використовують як комплексну характеристику кліматичних умов в екології загалом і дендрохронології - зокрема (Agricultural Encyclopedic Dictionary, 1989).

Зважаючи на важливе господарське, екологічне та соціальне значення насаджень за участю дуба звичайного, особливої актуальності набувають дослідження їхнього стану, росту, розвитку та біотичної стійкості в різних грунтово-кліматичних умовах, зокрема - у регіоні Полісся в період суттєвих кліматичних змін.
Об'єкти та методика досліджень. Об'єктом досліджень слугували середньовікові, пристигаючі i стиглі штучні насадження дуба звичайного Центрального Полісся України. Предмет досліджен$н я$ - особливості росту штучних деревостанів дуба звичайного за діаметром в умовах свіжих і вологих сугрудів. Метою досліджень було встановити оптимальні параметри метеорологічних чинників, які забезпечують максимальний приріст дерев дуба звичайного за діаметром в умовах свіжих і вологих сугрудів досліджуваного регіону.

Метеорологічні умови регіону досліджень охарактеризовані за даними метеостанції м. Коростень, яка найближче розташована до закладених тимчасових пробних площ і має довгострокову базу системних спостережень (рис. 1, 2).

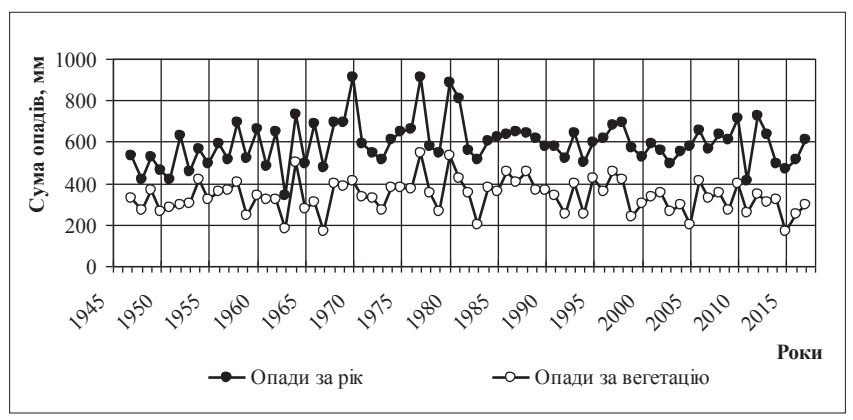

Рис. 1. Динаміка суми опадів у 1946-2018 pр.

За аналізом даних метеостанції м. Коростень, незважаючи на те, що в окремі роки спостерігаються різкі екстремуми температур і опадів, загалом встановлено тенденцію до зростання середньої температури повітря за рік та зменшення кількості опадів. При цьому, якщо кількость річних опадів наближається до кліматичної норми, то температура повітря в останні десятиріччя iї перевищує.

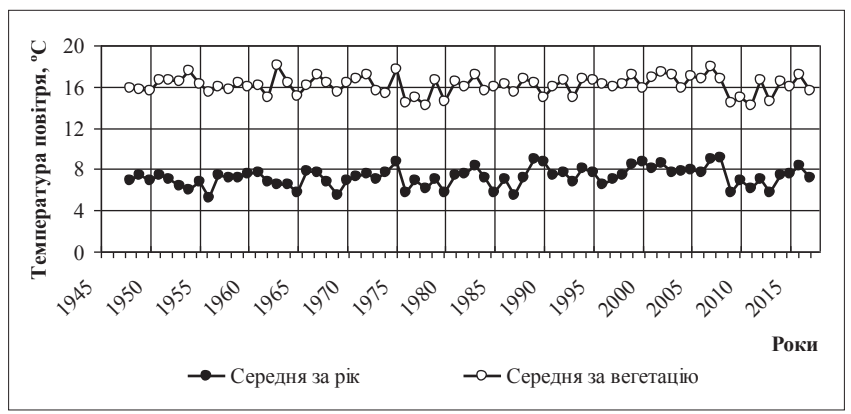

Рис. 2. Динаміка середньої температури повітря y $1946-2018$ pp.

Для оцінки річного приросту було закладено низку тимчасових пробних площ у насадженнях дуба звичайного в умовах свіжих і вологих сугрудів.

На тимчасових пробних площах підбирали модельні дерева (10-25 для пробної площі) шляхом випадкового розподілу майданчиків площею 200-250 м². Вимірювання ширини річних кілець здійснювали за допомогою інструмента Corim Maxi 3 точністю до 0,01 мм. Всього було оброблено 288 кернів, в яких виміряно 29684 радіальних 
приростів. На їх основі побудовано графік динаміки радіального приросту дубових деревостанів Центрального Полісся України за останні 70 років (рис. 3). За отриманими результатами, лінія тренду радіального приросту описується складним параболічним рівнянням третього порядку з дуже високою тіснотою зв'язку $(\mathrm{r}=0,91)$. На початкових етапах росту (до 20 років) приріст характеризувався максимальними значеннями (до 4,0 мм), що можна пояснити біологічними особливостями дуба звичайного, а також впливом кліматичних умов. Упродовж 1958-2003 рр. спостережено поступовий спад радіального приросту, після чого крива приростів до часу закінчення досліджень загалом стабілізується.

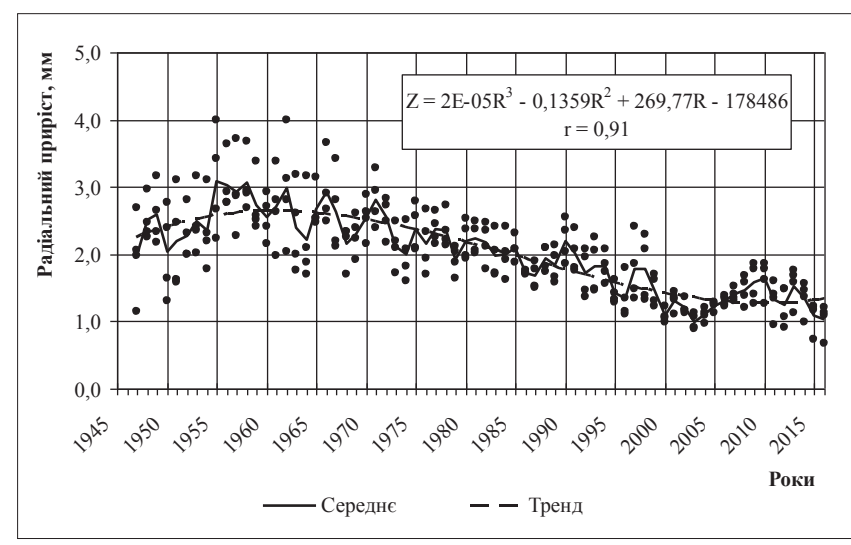

Рис. 3. Динаміка радіального приросту дуба звичайного

Вплив метеорологічних чинників (температури і опадів) на стовбурову продуктивність деревостану у насадженнях дуба звичайного оцінювали за коефіцієнтом кореляції між метеозначеннями і фактичним радіальним приростом.

Після обробки даних методом дисперсійного аналізу обчислено показники сили впливу. Як результативну ознаку використовували відносні індекси приросту для градацій чинників: річна сума опадів, опади за вегетаційний період, сума активних температур.

Аналіз зі встановлення зв'язку між радіальним приростом дуба і окремими метеорологічними чинниками здійснено шляхом зіставлення індексів приросту з відхиленням опадів і температури повітря від середньої багаторічної норми. При цьому обчислювали коефіцієнти кореляції між мінливістю радіального приросту і метеорологічних чинників за тривалі проміжки часу або окремі роки.

Впродовж усього періоду спостережень виявлено стійкі періодичні зміни (флуктуації) абсолютних значень радіальних приростів поблизу середнього (див. рис. 3). Середні значення приросту змінюються в межах вузького діапазону величин (1,0-3,0 мм).

Оскільки приріст є інтегральною характеристикою цілої низки чинників, під час обробки результатів досліджень і побудови порівняльних кривих динаміки радіального приросту за роками, залежно від впливу температури повітря і кількості опадів, застосовано метод індексів радіального поточного приросту, розроблений Rudakov (1958), який відображає радіальний приріст дерев у відносних безрозмірних величинах:

$$
I=i / i_{\text {cep. }} \cdot 100,
$$

де $I$ - індекс річного приросту в долях одиниці; $i-$ ширина річного шару; $i_{c e p .}$ - середня ширина річного шару на даному віковому етапі

Для досліджуваних лісорослинних умов графіки індексів радіального приросту дещо подібні, але мають певні відмінності на окремих вікових етапах (рис. 4).

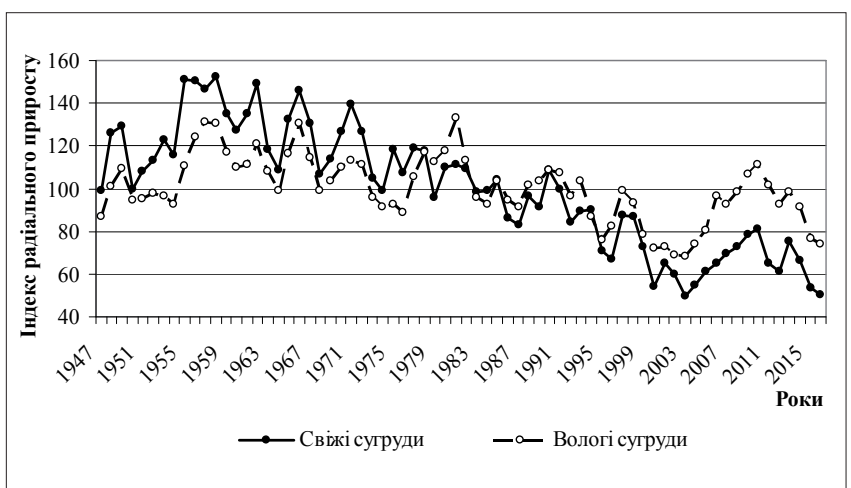

Рис. 4. Коливання індексів радіальних приростів у різних типах лісорослинних умов

Для виявлення загальних закономірностей динаміки радіальних приростів використано прийом обчислень індексів і згладжування цих величин у відношенні до ковзної середньої за 3-5 років. Біологічне обгрунтування та особливості проведення цих визначень викладені у роботах Bitvinskas (1987, 1998) (рис. 5).

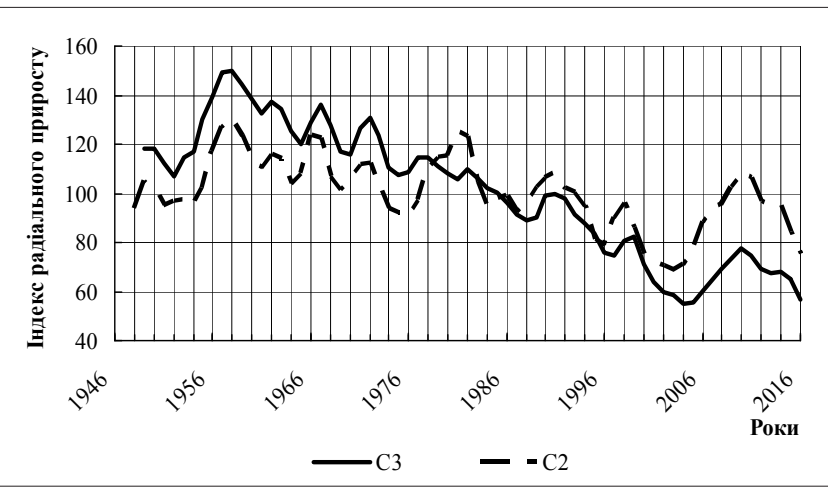

Рис. 5. Згладжені значення коливань індексів радіальних приростів дерев дуба звичайного у різних типах лісорослинних умов

Аналіз показав очевидне загальне зниження величин індексів радіальних приростів впродовж 1956-2002 pp. за збереження тенденції на обох типах з 2-4-річними циклічними коливаннями.

Для аналізу отриманих результатів застосовували методи математичної статистики (Shmidt, 1984) за залучення пакета MS Excel.

Результати та обговорення. Аналіз середніх багаторічних даних суми опадів за рік і вегетаційний період, а також суми активних температур у регіо- 
ні досліджень підтвердив, що ці показники загалом близькі до середньої багаторічної норми, характерної для Полісся. Статистична оцінка значень метеорологічних чинників (табл. 1) показала, що вони мають досить значну варіабельність середньої величини (18-26\%) за винятком суми активних температур, де коефіцієнт варіації становить лише 6,4\%.

Подібні статистичні показники варіабельності величин метеорологічних чинників отримали також інші дослідники (Bitvinskas, 1998; Kairukshtis et al., 1986; Kazmierczak, Zawieja, 2014; Maksymchuk et al., 2018), що вказує на доцільність використання згаданих вище метеорологічних чинників для 3'ясування їх зв'язків 3 радіальним приростом дерев.

Статистична оцінка значень індексів радіального приросту дерев дуба звичайного у свіжих і вологих сугрудах показала, що за практично однакового середнього значення вони відзначаються суттєвими коливаннями за високого коефіцієнта мінливості, відповідно, 28,3 та 15,3\% (табл. 2). Це вказує на відчутнішу реакцію дерев дуба звичайного у свіжому сугруді на зміну кліматичних чинників, порівняно $з$ дубовими насадженнями вологого сугруду.

Таблиия 1

\section{Статистичні показники досліджених метеорологічних чинників (1947-2017рр.)}

\begin{tabular}{lcccc}
\hline \multirow{2}{*}{\multicolumn{1}{c}{ Показник }} & \multicolumn{2}{c}{ Сума опадів, мм } & & Сума температур \\
\cline { 2 - 3 } & щорічна & за V-IX місяці & & ГТК \\
\hline Середне значення & 593,4 & 343,7 & 2380,3 & 1,45 \\
Стандартна похибка & 13,84 & 10,05 & 19,32 & 0,048 \\
Стандартне відхилення & 109,0 & 79,2 & 152,13 & 0,38 \\
Дисперсія & 11875,1 & 6266,6 & 23143,0 & 0,14 \\
Мінімум & 342 & 164 & 2007 & 0,63 \\
Максимум & 912 & 546 & 2716 & 2,55 \\
Коефіцієнт варіації (V), \% & 18,4 & 23,0 & 6,4 & 25,8 \\
Точність досліду, \% & 2,3 & 2,9 & 0,8 & 3,3 \\
\hline
\end{tabular}

Примітка: чисельник - ГТК - гідротермічний коефіцієнт.

Варіаційно-статистичні показники індексів радіальних приростів дуба звичайного в сугрудах різних гігротопів

\begin{tabular}{lcc}
\hline \multirow{1}{*}{\multicolumn{1}{c}{ Показник }} & \multicolumn{2}{c}{ Тип лісорослинних } \\
\cline { 2 - 3 } & $C_{2}$ & $C_{3}$ \\
\hline Середнє значення & 100,0 & 99,9 \\
Стандартна похибка & 3,38 & 1,83 \\
Стандартне відхилення & 28,3 & 15,3 \\
Дисперсія & 799,6 & 234,5 \\
Мінімум & 49,6 & 68,2 \\
Максимум & 152,3 & 133,1 \\
Коефіцієнт варіації (V), \% & 28,3 & 15,3 \\
Точність досліду, \% & 3,3 & 1,8 \\
\hline
\end{tabular}

За наведеними даними (див. рис. 4,5 ) екстремуми (мінімуми і максимуми) індексів радіального приросту дуба звичайного у свіжих і вологих сугрудах в основному співпадають. Найглибші депресії приросту пов'язані з посушливими роками.

Реакція дерев дуба звичайного на зміну умов середовища проявляється по-різному. Після катастрофічних посух 1972 та 2002 рр. приріст дерев дуба знижувався істотніше у свіжих гігротопах сугрудів порівняно $з$ вологими.

Аналіз реакції узагальненого радіального приросту, його індексу на метеорологічні показники (температура повітря, атмосферні опади і похідний від них гідротермічний коефіцієнт зволоження) показав, що незначний позитивний вплив на радіальний приріст дерев дуба має сума опадів за вегетацію, ще менший - за рік. Значення коефіцієнта кореляції склали від 0,16 до 0,22 (при $\mathrm{p}<0,05$ ).

Опади осінніх і зимових місяців попереднього року також мають невеликий позитивний вплив, як наслідок нагромадження певних запасів вологи у грунті до моменту початку камбіальної активності $(\mathrm{r}=0,14)$. Достовірного зв'язку індексу радіального приросту з опадами за окремі місяці весняно-літнього періоду на цьому етапі досліджень не виявлено.

Причини низької кореляції приросту з опадами заслуговують детальнішого аналізу і обговорення 3 урахуванням ефектів післядії і специфічності реакцій дерев на значні відхилення суми опадів від середніх багаторічних значень.

Стосовно впливу температури повітря встановлено, що роки з найбільш високими і низькими значеннями радіального приросту слабо відрізняються за середньомісячними температурами. Цей висновок узгоджується з даними Bitvinskas $(1987,1998)$, який не виявив корелятивного зв'язку між приростом і середніми температурами за червень-серпень. 
У той же час встановлено наявність тісного зв'язку між індексом ширини річного кільця та показниками гідротермічного коефіцієнта. У понад 90\% дерев дуба звичайного підвищені прирости 3 індексом $>80$ формуються у зволожені роки 3 характерним зональним середнім багаторічним ГТК не меншим 1,5. За межами значень ГТК (від 1,4 до $1,8)$ знаходиться зона пригнічення зі зниженими індексами радіального приросту (рис. 6,7 ).

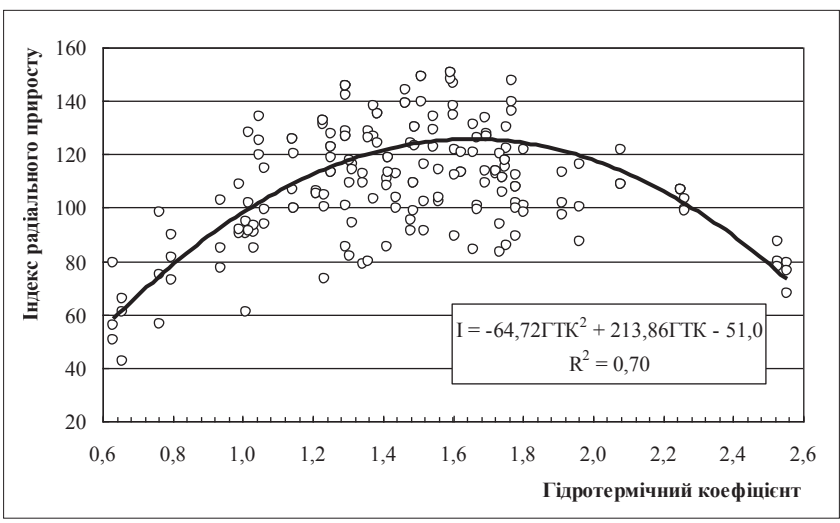

Рис. 6. Залежність індексів радіального приросту дуба від гідротермічного коефіцієнта в умовах свіжого сугруду

Залежність між індексом приросту дуба в умовах свіжого сугруду і гідротермічним коефіцієнтом апроксимується параболічною кривою за значного показника ступеня зв'язку $\left(\mathrm{r}^{2}=0,70\right)$.

Згідно отриманої залежності, оптимум зростання дуба у свіжих сугрудах (максимальне значення індексу радіального приросту I = 125,7$)$ досягається за ГТК $=1,65$.

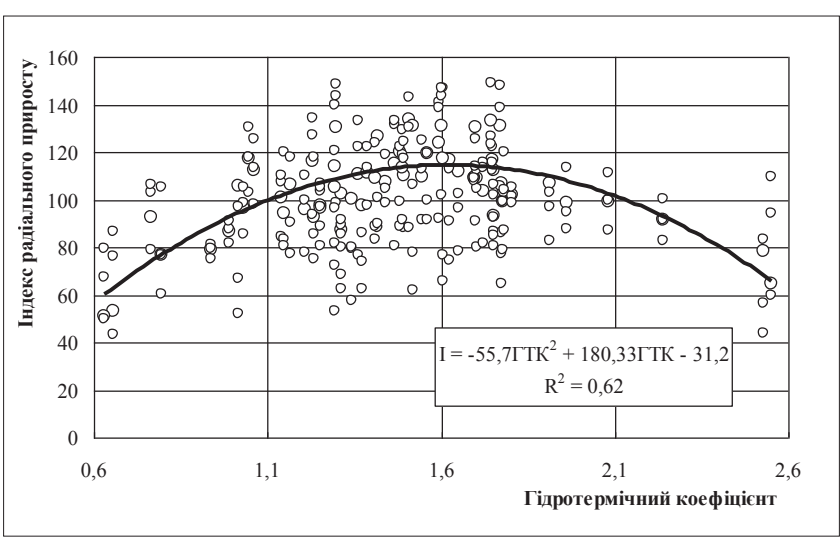

Рис. 7. Залежність індексів радіального приросту дуба від гідротермічного коефіцієнта в умовах вологого сугруду

Залежність індексу радіального приросту дуба від гідротермічного коефіцієнта в умовах вологого сугруду за характером апроксимації подібна до попередньої за значного показника тісноти зв'язку $\left(\mathrm{r}^{2}=0,62\right)$. Ця функція досягає максимального значення $(\mathrm{I}=114,8)$ за ГТК $=1,62$.

Отже, оптимальні для росту деревостанів дуба звичайного показники ГТК для свіжих і вологих сугрудів відрізняються несуттєво - на 1,9\%. При цьо- му, індекс радіального приросту значно більший у свіжому сугруді $(125,7$ проти 114,8 у вологих умовах), що підтверджує висновок про вищу чутливість дерев дуба звичайного у свіжому сугруді до дії метеорологічних чинників.

Висновки. Незначний позитивний вплив на радіальний приріст дерев дуба звичайного виявляють річна сума опадів $(\mathrm{r}=0,16)$, сума опадів за вегетаційний період $(\mathrm{r}=0,22)$ та опади осінніх і зимових місяців попереднього року $(\mathrm{r}=0,14)$. Роки з найбільш високими і низькими величинами радіального приросту слабо відрізняються за показниками середньомісячних температур повітря. Встановлено наявність тісного зв'язку між індексом ширини річного кільця з показниками гідротермічного коефіцієнта. У понад $90 \%$ дерев дуба звичайного підвищені прирости з індексом $>80$ формуються в роки зі значеннями ГТК від 1,4 до 1,8.

Оптимальні для росту деревостанів дуба звичайного значення ГТК для свіжих і вологих сугрудів становлять, відповідно, 1,65 та 1,62. При цьому індекс радіального приросту значно більший в умовах свіжого сугруду $(125,7$ проти 114,8 у вологих умовах), що вказує на більшу чутливість дерев дуба у свіжому сугруді до поліпшення погодних умов.

Виявлені кореляційні зв'язки між радіальним приростом і кліматичними показниками в подальшому можуть бути використані для побудови кліматичних реконструкцій та прогнозу продуктивності дубових деревостанів.

\section{References}

Agricultural Encyclopedic Dictionar (1989). Moskov: Soviet encyclopedia. Retrieved from https://www. twirpx.com/file/375104/ (in Russian).

Bitvinskas, T. (1987). Formulation of the fundamentals of dendroclimatological research in Lithuanian SSR. Soviet publications in dendrochronology (eds. V. Lamarche, M. Gibson). Tucson, Tree Ring Society, 3, 4-48.

Bitvinskas, T. (1998). Development and trends of dendrochronology in Lithuania. Proceedings of International Conference «Eurodendro-98»: Dendrochronology and Environmental Trends (eds. V. Stravinskienè and R. Juknys). Kaunas, Vytautas Magnus University, 77-83.

Debryniuk, Iu.M., Krynitskyy, G.T., \& Tselen, Ya.P. (2016). Technology of forest plantation cultivation in the western region of Ukraine. Lviv: Kamula (in Ukrainian).

Ivanyuk, I., Zborovska, O., \& Zhukovskyi, O. (2019). Dynamics of radial increment of the premature oak stands in fairly fertile site type with varying humidity degree of Polissya in Ukraine. Miškininkystè, 2 (84), 71-76. Retrieved from https://www.google.com/se arch? $\mathrm{q}=\mathrm{Mi} \% \mathrm{C} 5 \% \mathrm{~A} 1$ kininkyst $\% \mathrm{C} 4 \% 97 \% 2 \mathrm{C} \% 20$ 2019\%20Nr.\%202\%20(84)

Fuchylo, Ya.D. (2011). Plantation Forestry: Theory, Practice, Perspectives. Kyiv: Logos (in Ukraine). 
Kairukshtis, L.A., Galaziy, G.I., \& Shiyatov, S.G. (1986). Dendrochronology and dendroclimatology. Novosibirsk: Science, Siberian Branch (in Russian).

Kazmierczak, K., \& Zawieja, B. (2014). The influence of weather conditions on annual height increments of Scots Pine. Biometrical Letters, 51 (2), 143-152. https://doi.org/10.2478/bile-2014-0010

Kobal, M., Greman, H., Zupan, M., Levanic, T., Simoncic P., Kadunc, A., \& Hladnik, D. (2015). Influence of soil properties on silver fir (Abies alba Mill.) growth in the Dinaric Mountains. Forest Ecology and Management, 337, 77-87. http://dx.doi. org/10.1016/j.foreco.2014.10.017.

Maksymchuk, R.T., Sopushynskyy, I. M., \& Tymochko, I. Ya. (2017). Peculiarities of the formation of the annual ring and the base density of straight-fibrous and undulating-wavy wood of Abies alba Mill. Scientific Bulletin of Ukrainian National Forestry University, 27.9, 30-33. https://doi.org/10.15421/40270906. (in Ukrainian)

Maksymchuk, R.T., Sopushinskyy, I.M., Kopolovets, Ya. M., \& Zayachuk, V. Ya. (2018). Internal species differentiation of Abies alba Mill. behind the structure of wood. Scientific Bulletin of Ukrainian National Forestry University, 28.7, 44-48. https:// doi.org/10.15421/40280709 (in Ukrainian)

Osazuwa-Peters, O.L., Wright, S. J., \& Zanne, A.E. (2014). Radial variation in wood specific gravity of tropical tree species differing in growth-mortality strategies. American Journal of Botany, 101, 803811. https://doi.org/10.3732/ajb.1400040.

Rudakov, V.E. (1958). On the methodology for studying the influence of climate fluctuations on the width of tree rings. Botanical journal, 43 (12), 17091712 (in Russian).

Shmidt, V.M. (1984). Mathematical Methods in Botany: schoolbook. Leningrad: Publishing house of Leningrad University (in Russian).

Sopushynskyy, I., Kharyton, I., Teischinger, A., Mayevskyy, V., \& Hrynyk, H. (2016). Wood density and annual growth variability of Picea abies (L.) Karst. growing in the Ukrainian Carpathians. European Journal Wood Products, 75 (3), 419-428. https://doi.org/10.1007/s00107-016-1079-1.

Sopushynskyy, I., Kopolovets, Ya., Tymochko, I., \& Maksymchuk, R. (2019). The influence of forest types on the volumetric mass of Scots pine wood in the forest conditions of the Carpathian region. Ştiinţa agricolă, 2, 79-84. https://doi.org/10.5281/ zenodo.3596664 (in Russian)

Szaban, J., Kowalkowski, W., Karaszewski, Z., \& Jakubowski, M. (2014). Effect of tree provenance on basic wood density of Norway spruce (Picea abies [L.] Karst.) grown on an experimental plot at Siemianice Forest Experimental Station. Drewno, 57 (191), 135-144. https://doi.org/10.12841/wood.16443985.061.10.

Wasik, R., Michalec, K., \& Barszcz, A. (2015). The variability of certain macrostructural features and the density of grand fir (Abies grandis Lindl.) wood from selected stands in southern Poland. Drewno, 58
(195), 45-58. https://doi.org/10.12841/wood.16443985.118.04

Zhang, L., Jiang, Yu., Zhao, Sh., Jiao, L. \& Wen, Ya. (2018). Relationships between Tree Age and Climate Sensitivity of Radial Growth in Different Drought Conditions of Qilian Mountains, Northwestern China. Forests, 9, 135. https://doi.org/10.3390/f9030135.

\section{Влияние метеорологических факторов на радиальный прирост деревьев дуба черешчатого в условиях свежих и влажных сугрудов Полесья Украины}

\author{
И.Д. Иванюк' Я.Д. Фучило²
}

Учитывая важное экономическое, экологическое и социальное значение лесов с участием дуба черешчатого, изучение их состояния, роста, развития и биологической устойчивости в различных природных зонах под воздействием климатических факторов является особенно актуальным.

Объектом исследования стали древостои дуба черешчатого старших возрастных групп, произрастающие в условиях Полесья Украины. Цель исследования - установление оптимальных параметров метеорологических факторов, обеспечивающих максимальный прирост деревьев дуба по диаметру в условиях свежих и влажных сугрудов Полесья.

Для оценки годового прироста дуба черешчатого было заложено ряд временных пробных площадей в свежих и влажных условиях с последующим выделением модельных деревьев (10-25 на каждой пробной площади). Измерения ширины годичных колец модельных деревьев проводили с помощью инструмента «Corim Мaxi» с точностью до 0,01 мм.

Для анализа результатов использован индекс радиального прироста: $I=i / i_{\text {средне }} \cdot 100$, где $I$ - показатель годичного прироста по диаметру в долях единицы; $i$ - ширина годового слоя; $i_{\text {среднее }}-$ средняя ширина годового слоя в этом возрасте. Анализ зависимостей между метеорологическими факторами и радиальным приростом деревьев дуба показал, что незначительное положительное влияние на радиальный прирост имеют годовая сумма осад-

Иванюк Игорь Дмитриевич - кандидат сельскохозяйственных наук, доцент, директор Малинского лесотехнического колледжа, представитель Коллективного члена ЛАН Украины, 11643, с. Гамарня Малинского района Житомирской области, Украина. Тел. +38-041-336-85-13. E-mail: mltk-1927@ukr.net ORCID: 0000-0002-4969-8783

Фучило Ярослав Дмитриевич - академик Лесной академии наук Украины, доктор сельскохозяйственных наук, профессор, заведующий кафедры лесоводства и защиты леса Малинского лесотехнического колледжа, главный научный сотрудник Института биоэнергетических культур и сахарной свеклы НААН Украины, ул. Клиническая, 25, г. Киев, 03141, Украина. Тел. +38-067-605-91-41. E-mail: fuchylo_yar@ukr.net ORCID: http:// orcid.org/0000-0002-2669-5176 
ков $(\mathrm{r}=0,16)$, сумма осадков за вегетацию $(\mathrm{r}=0,22)$, осадки осенних и зимних месяцев предыдущего года $(\mathrm{r}=0,14)$. Установлено, что годы наиболее высоких и низких величин радиального прироста мало отличаются по среднемесячным температурам воздуха. В то же время установлено наличие тесной связи индекса ширины годичного кольца с показателями гидротермического коэффициента - отношения суммы осадков (P) за вегетационный период к десятой части суммы температур $(\mathrm{t})$ выше $10^{\circ} \mathrm{C}$ $\left(\Gamma \mathrm{TK}=\mathrm{P} / 0,1 \Sigma \mathrm{t} \geq 10^{\circ} \mathrm{C}\right)$. У более $90 \%$ деревьев дуба обыкновенного повышенные приросты с индексом $>$ 80 формируются в годы с показателями ГТК от 1,4 до 1,8 . Вне этого интервала находится зона торможения роста деревьев с пониженными показателями радиального прироста. На основе математического моделирования зависимости между индексом радиального прироста и гидротермическим коэффициентом установлено, что оптимальные для роста древостоев дуба черешчатого показатели ГТК для свежих и влажных сугрудов составляют соответственно 1,65 и 1,62 . При этом индекс радиального прироста значительно больше в свежем сугруде (125,7 против 114,8 во влажных условиях), что указывает на большую чувствительность деревьев дуба в свежем сугруде к изменению погодных условий.

Выявленные корреляционные связи параметров радиального прироста с климатическими показателями в дальнейшем могут быть использованы для построения климатических реконструкций и прогноза продуктивности дубовых древостоев в будущем.

Ключевые слова: Quercus robur L.; древостои старших возрастных групп; количество осадков; сумма температур воздуха; гидротермический коэффициент; годовой прирост по диаметру; индекс радиального прироста.

\section{Influence of meteorological factors on the radial increase of English oak trees in the fresh and moist fairly fertile forest types conditions of the Ukrainian Polissya}

\section{Ivanyuk ${ }^{1}$, Y. Fuchylo ${ }^{2}$}

The important economic, ecological and social functions of the forests with the participation of

Ihor Ivanyuk - Ph.D. in Agricultural Sciences, Docent, Director of the Malyn Forestry College, Representative of the Collective Member of the Forest Academy of Sciences of Ukraine, 11643, v. Hamarnya, Malyn district, Zhytomyr region, Ukraine. Tel. +38041-336-85-13. E-mail: mltk-1927@ukr.net ORCID: 0000-00024969-8783

Yaroslav Fuchylo - Full Member of the Forestry Academy of Sciences of Ukraine, Doctor of Agricultural Sciences, Professor, Head of the Department of Forestry and Forest Protection of Malyn Forestry College, Chief Scientist. Institute of Bioenergy Crops and Sugar Beet, National Academy of Agrarian Sciences of Ukraine, 03141, Clinical str., 25, Kyiv city, Ukraine. Tel.: +38-067-605-9141. E-mail: fuchylo_yar@ukr.net ORCID:http://orcid.org/00000002-2669-5176
English oak are presented., The study of their growth conditions, development and biological stability in different natural zones under the climatic factors influence is especially relevant.

The research object is the of English oak stand of older age groups which grows in the Ukrainian Polissya.

The research purpose is to establish the optimal parameters of meteorological factors that provide the maximum growth in diameter of oak trees in the conditions of fresh and moist fairly fertile forest type of the Polissya.

To assess the annual increment of English oak, a number of temporary test plots were laid in the fresh and wet conditions.

The model trees (10-25 for each trial plots) were selected. Measurements of the width of the annual rings of model trees were performed with the tool «Corim Maxi» with an accuracy of $0.01 \mathrm{~mm}$.

To analyze the results relative indicators used: the index of radial increase: $I=i / i_{\text {average }} \cdot 100$, where $I-$ annual growth index in shares of the unit; $i$ - the width of the annual layer; $i_{\text {average }}$ - the average width of the annual layer at this age. An analysis of the correlation among the meteorological factors and the radial growth of oak trees showed that the annual precipitation $(\mathrm{r}=0.16)$, the amount of precipitation during the vegetation season $(r=0.22)$ and the rainfall of the autumn and winter months of the previous year $(\mathrm{r}=0.14)$ have a slight positive effect on the radial increase of oak trees. It has been established that the years of the highest and lowest values of radial increase depended little in average monthly air temperatures. At the same time, it was found that there is a close correlation between the annual ring width index and the hydrothermal coefficient (HTK - the ratio of precipitation quantity over the growing season $(\mathrm{P}, \mathrm{mm})$ to a tenth of the sum of temperatures $\left(\mathrm{t},{ }^{\circ} \mathrm{C}\right)$ above $10{ }^{\circ} \mathrm{C}\left(H T K=P / 0.1 \Sigma t \geq 10^{\circ}\right)$. In more than $90 \%$ of English oak trees, highest growths with an index $>80$ are formed in the years with HTK indices from 1.4 to 1.8. Outside this interval there is a zone of inhibition of trees growth with the lowered indices of radial increase.

On the basis of mathematical modelling of the correlation between the radial growth index and the hydrothermal coefficient, it was found that the HTK values for fresh and wet fairly fertile forest types optimal for the growth of ordinary oak stands are 1.65 and 1.62 , respectively. At the same time, the radial growth index is much higher in fresh fairly fertile forest type (125.7 versus 114.8 in humid conditions), which indicates a greater sensitivity of oak trees in fresh fairly fertile forest type to changes in weather conditions.

The revealed correlations between the parameters of radial growth and climatic indicators can be used in the future for constructing climatic reconstructions and forecasting the oak stands productivity in the future.

Key words: Quercus robur L.; stands of older age groups; rainfall; total air temperature; hydrothermal coefficient; annual diameter increase; radial growth index. 